Volume 10 No. 1 Maret 2019

P-ISSN 2086-6178 E-ISSN 2579-3292

http://ejournal.bsi.ac.id/ejurnal/index.php/jkom

\title{
Pemanfaatan Teknologi Video Streaming Di LPP TVRI Jawa Barat
}

\author{
Lia Kurniawati \\ Politeknik Kridatama \\ email: liakurniawati@politeknik-kridatama.ac.id
}

Cara Sitasi: Kurniawati, L. (2019). Pemanfaatan Teknologi Video Streaming Di LPP TVRI Jawa Barat. Jurnal Komunikasi, 10(1), 10-18.

\begin{abstract}
LPP TVRI is the first TV station to utilize video streaming technology and LPP TVRI West Java's in it. This research is to find out the extent of the development of the broadcasting world, especially on television in LPP TVRI West Java, by utilizing the internet network. The method uses descriptive approach according to the object of research. The techniques used based on the above, Video streaming technology that is used, is intended to meet the needs of the public for information and entertainment. Audiences outside the home, such as in the office, café or outside the West Java region can easily and practically watch the national LPP TVRI program through smartphones and / or various gadgets using youtube or applications that can be downloaded in the playstore. The advantages of video streaming technology, among others, the network chose separately, especially in video streaming so that there are no network constraints. The missed program can be witnessed by selecting catchup TV contained in the TVRI live streaming application. Free and easy, and can choose the desired program. The disadvantages are: LPP TVRI West Java's live streaming programs can be watched starting at 3:00 p.m. on the news program until 9:00 p.m. on the music program. The LPP TVRI West Java program title that is available on YouTube when selected is still empty, so the user must type desired program on search engine. The obstacle faced by LPP TVRI West Java in video streaming is the internet network used by users.
\end{abstract}

Keywords: TVRI Jabar, Life Streaming, Aplication, Technologi, video streaming

\section{PENDAHULUAN}

Penggabungan beberapa bidang sekaligus yakni Teknologi informasi dan komunikasi merupakan satu keunggulan dari penelitian yang disajikan dibandingkan dengan beberapa penelitian sebelumnya dimana penelitian ini menitik beratkan pada penggabungan antara teknologi informasi, informatika dan komunikasi massa dimana hal ini terkait dengan segala kegiatan pemprosesan, manipulasi, pengelolaan, pemindahan informasi antar media. Perkembangan teknologi informasi dan komunikasi yang begitu pesat dapat kita manfaatkan pada media elektronik audio visual yang dapat melibatkan dua indra sekaligus, yaitu indra pendengaran dan indra penglihatan yang merupakan gabungan dari media auditif dan visual. Media audio visual ini dirasa cukup efektif dan efisien dalam menyampaikan informasi, sehingga khalayak dapat dengan mudah memahami isi informasi yang disampaikan.
Tinjauan Pustaka dari beberapa literatur mengenai video streaming sebagai berikut, menurut Kurniawan, (Video Streaming atau Streaming media (aliran media), juga disebut streaming video dan streaming audio, adalah perangkat lunak yang digunakan untuk mempercepat transmisi video dan audio melalui Internet. Video streaming sering disebut sebagai tayangan langsung yang dibroadcast pada banyak orang dalam waktu yang bersamaan dengan kejadian aslinya, melalui media data komunikasi (network) baik yang terhubung dengan kabel dan wireless. Sudut pandang lain menurut Silalahi (2013), Penggunaan video streaming melalui Internet pada saat ini semakin meningkat. Peningkatan jumlah penggunaan video streaming seiring dengan peningkatan penggunaan teknologi jaringan tanpa kabel. Karakteristik video streaming membutuhkan penanganan berbeda dibandingkan dengan transmisi data teks pada umumnya.

Televisi merupakan teknologi informasi yang paling luas penyebarannya, dengan kemajuan teknologi, 
penyiaran televisi dapat menyebar ke sarana lain yaitu internet. Kebutuhan masyarakat akan informasi dan hiburan sudah menjadi konsumsi sehari-hari. Setiap stasiun tv mempunyai program acara yang berbeda disetiap waktunya, masyarakat berhak memilih program acara yang akan disaksikan. Disini stasiun tv dituntut untuk dapat memanfaatkan kemajuan teknologi tersebut.

Teknologi yang dapat dimanfaatkan untuk penyiaran televisi adalah video streaming, LPP TVRI Jawa Barat merupakan stasiun tv pertama yang memanfaatkan teknologi video streaming. Sebenarnya ada 2 layanan yang dapat digunakan oleh internet yaitu on demand dan livecasting. Jenis layanan on demand adalah menyiarkan file media yang telah direkam sebelumnya, sedangkan livecasting menyiarkan file media ketika kejadian tengah berlangsung.

Penyiaran program acara secara streaming sangat praktis dan mudah, dengan menggunakan browser internet kita sudah dapat menikmati berbagai acara secara online baik program acara di dalam dan di luar negeri. Siaran secara streaming dapat dinikmati pada komputer, tablet, smartphone, hp android, Iphone, Ipad dan sebagainya, hanya saja koneksi internet harus stabil.

\section{METODOLOGI PENELITIAN}

Uji coba penelitian mengenai pemanfaatan teknologi video streaming di LPP TVRI Jawa Barat, memiliki maksud dan tujuan yaitu peran media televisi khususnya di LPP TVRI Jawa Barat dalam memanfaatkan perkembangan kemajuan teknologi, sehingga LPP TVRI Jawa Barat tidak tertinggal oleh stasiun tv lokal maupun nasional yang telah memanfaatkan teknologi video streaming, berdasarkan hasil penelitian uji coba dengan beberapa penyajian berbagai program acara dilakukan secara streaming.

Pengukuran efektifitas pemanfaatan video streaming di LPP TVRI Jawa Barat dengan melihat, mengamati dan mendokumentasikan langsung dengan menggunakan berbagai media online berbasis internet dengan menentukan beberapa segmentasi khalayak.

\section{HASIL DAN PEMBAHASAN}

Definisi komunikasi massa yang paling sederhana dikemukakan oleh Bittner (Rakhmat, 2003: 188), yakni: komunikasi massa adalah pesan yang dikomunikasikan melalui media massa pada sejumlah besar orang (mass communication is messages communicated through a mass medium to a large number of people).

Harold D. Lasswell mengemukakan suatu ungkapan yang sangat terkenal dalam teori dan penelitian komunikasi massa. Merupakan suatu formula dalam menentukan scientific study dari suatu proses komunikasi massa dengan menjawab pertanyaanpertanyaan sebagai berikut: who (siapa), says what (berkata apa), in which channel (melalui saluran apa), to whom (kepada siapa) dan with what effect (dengan efek apa)?

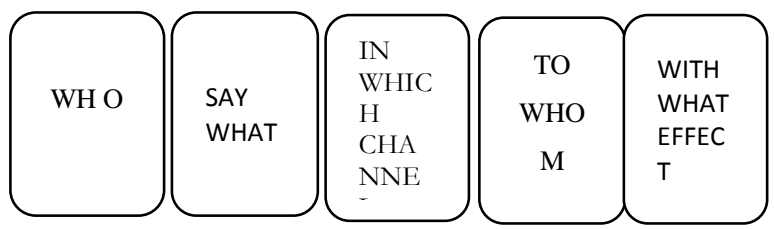

Gambar Bagan Komunikasi Menurut Lasswell

Dengan mengikuti formula Lasswell dapat dipahami bahwa dalam proses komunikasi massa terdapat lima unsur yang disebut komponen atau unsur dalam proses komunikasi, yaitu: Komunikator, Pesan, Saluran (Media), Komunikan, Efek.

Media Massa ; Media Cetak (Surat Kabar, Majalah), Media Elektronik (Radio, Televisi dan Internet). Fungsi Media Massa, Sejumlah peneliti mengklasifikasikan berbagai penggunaan dan kepuasan ke dalam empat kategori system : Cognition (kognisi/pengetahuan). Kognisilah yang mendasari tindakkan seseorang untuk mengetahui sesuatu. Seseorang menggunakan media massa untuk memperoleh informasi tentang sesuatu, kemudian dia menggunakan media sebagai bagian dari kognisi.

Lebih jauh, kognisi yang dimiliki individu dalam menggunakan media secara langsung sama dengan fungsi pengawasan (surveillance function) pada tingkat analisis makro. ; Diversion (hiburan). Kebutuhan dasar lainnya pada manusia adalah hiburan. Hiburan dapat diperoleh melalui beberapa bentuk yang dikemukakan para peneliti sebagai berikut: (1) Stimulation atau pencarian untuk mengurangi rasa bosen atau melepaskan diri dari kegiatan rutin; (2) Relaxation (santai) atau pelarian dari tekanan dan masalah; dan (3) Emotional release (pelepasan emosi) dari perasaan dan energi yang terpendam. (4) Social utility (kepentingan sosial). 
Pakar psikologi mengidentifikasikan penetapan integrasi social, mencakup kebutuhan untuk mempekuat hubungan dengan keluarga, teman dan yang lainnya dalam masyarakat. Fungsi media untuk memenuhi kebutuhan ini disebut dengan social utility. Kebutuhan ini diperoleh melalui pembicaraan atau diskusi tentang sebuah program TV, film terbaru, atau program radio siaran terbaru. Media menjadi convenstional currency (pembiacaraan topik yang hangat).

Media memberikan kesamaan landasan untuk pembicaraan masalah social. (5) Withdrawal (pelarian). Orang menggunakan media tidak hanya untuk tujuan santai, tetapi juga sebagai withdrawal (pelarian). Orang menggunakan media massa untuk mengatasi rintangan antara mereka dan orang-orang lain, atau untuk menghindari aktivitas lain.

\section{Sejarah Televisi}

Prinsip televisi ditemukan oleh Paul Nipkow dari Jerman pada tahun 1884, namun baru tahun 1928 Vladimir Zworkyn (Amerika Serikat) menemukan tabung kamera atau iconoscope yang bisa menangkap dan mengirim gambar ke kotak bernama televisi. Iconoscope bekerja mengubah gambar dari bentuk gambar optis ke dalam sinyal elektronis untuk selanjutnya diperkuat dan ditumpangkan ke dalam gelombang radio. Zworklyn dengan bantuan Philo Farnsworth berhasil menciptakan pesawat televisi pertama yang dipertunjukkan kepad umum pada pertemuan World's Fair pada tahun 1939.Kemunculan televisi pada awalnya ditanggapi biasa saja oleh masyarakat. Harga pesawat televisi ketika itu masih mahal, selain itu belum tersedia banyak program untuk disaksikan. Pengisi acara televisi pada masa itu bahkan meragukan masa depan televisi, mereka tidak yakin bahwa televisi dapat berkembang dengan pesat.

Perang Dunia ke-2 sempat menghentikan perkembangan televisi. Namun setelah perang dunia usai, teknologi baru yang telah disempurnakan selama perang, berhasil mendorong kemajuan televisi. Kamera televisi baru tidak lagi membutuhkan banyak cahaya sehingga para pengisi acara di studio tidak lagi kepanasan. Selain itu, layar televisi sudah menjadi besar, terdapat lebih banyak program yang tersedia dan sejumlah stasiun televisi lokal mulai membentuk jaringan. Masa depan televisi mulai terlihat menjanjikan.

Awalnya di tahun 1945, hanya terdapat delapan stasiun televisi dan 8000 pesawat televisi di seluruhAS. Namun sepuluh tahun kemudian, jumlah stasiun televisi meningkat menjadihampir 100 stasiun sedangkan jumlah rumah tangga yang memiliki pesawat televisi mencapai 35 juta rumah tangga atau 67 persen dari total rumah tangga.

Semua program televisi pada awalnya ditayangkan dalam siaran langsung (live). Pertunjukkan opera di NEW York menjadi program favorit televisi dan disiarkan secara langsung. ketika itu, belum ditemukan kaset penyimpanan suara dan gambar (videotape). Pengisi acara televisi harus mengulang lagi pertunjukkannya beberapa kali agar dapat disiarkan pada kesempatan lain. Barulah pada tahun 1956, Ampex Corporation berhasil mengembangkan videotape sebagai sarana yang murah dan efisien untuk menyimpan suara dan gambar program televisi. Pada awal tahun 1960-an hampir seluruh program, yang pada awalnya disiarkan secara langsung, diubah dan disimpan dalam videotape. Pesawat televisi berwarna mulai diperkenalkan kepada publik pada tahun 1950-an. Siaran televisi berwarna dilaksanakan pertama kali oleh stasiun televisi NBC pada tahun 1960 dengan menayangkan program siaran berwarna selama tiga jam setiap harinya.

\section{Sejarah Internet}

Sejarah Internet dimulai dengan pengembangan komputer elektronik pada 1950-an. Awal konsep tentang jaringan paket berasal dari beberapa laboratorium ilmu komputer di Amerika Serikat, Inggris, dan Perancis. Departemen Pertahanan Amerika memberikan kontrak pada awal 1960-an untuk sistem jaringan paket, termasuk pengembangan ARPANET (yang akan menjadi jaringan pertama yang menggunakan protokol internet).

Akses ke ARPANET diperluas pada tahun 1981 ketika National Science Foundation (NSF) didanai oleh Computer Science Network (CSNET). Pada tahun 1982, protokol internet TCP/IP diperkenalkan sebagai protokol jaringan standar pada ARPANET. Pada awal 1980-an NSF mendanai pendirian pusat superkomputer nasional di sejumlah perguruan tinggi, dan dengan proyek NSFNET memberikan interkonektivitas pada tahun 1986, yang juga menciptakan akses jaringan untuk organisasi penelitian dan pendidikan ke lokasi superkomputer di Amerika Serikat.

Internet Service Provider (ISP) mulai muncul pada akhir 1980-an. Pada tahun 1990 ARPANET dinonaktifkan, membuat koneksi pribadi ke internet oleh entitas komersial menjadi meluas dengan cepat. Kemudian pada tahun 1995 NSFNET dinonaktifkan juga, sehingga menghilangkan penghalang terakhir bagi penggunaan internet secara komersial. Sejak 
pertengahan 1990-an, Internet telah membawa dampak revolusioner pada aspek budaya dan perdagangan, termasuk bangkitnya komunikasi instan melalui email, pesan instan, panggilan telepon voice over Internet Protocol (VoIP), panggilan video interaktif dua arah, dan World Wide Web dengan forum diskusinya, blog, jejaring sosial, dan situs belanja online.

Komunitas peneliti dan pendidikan terus mengembangkan dan menggunakan jaringan canggih seperti very high speed Backbone Network Service (vBNS) milik NSF, Internet2, dan National LambdaRail. Hal ini meningkatkan jumlah data yang ditransmisikan pada kecepatan yang lebih tinggi dan lebih tinggi lagi melalui jaringan fiber optic yang beroperasi pada $1 \mathrm{Gbit} / \mathrm{s}, 10 \mathrm{Gbit} / \mathrm{s}$, atau lebih.

Perkembangan internet menjadi alat komunikasi global bagi semua orang hampir berjalan dengan instan dalam sejarah. Pada tahun 1993 hanya 1\% informasi yang mengalir melalui jaringan internet, tahun 2000 meningkat 51\%, dan lebih dari 97\% informasi telah dikomunikasikan pada tahun 2007. Saat ini, Internet terus berkembang, didorong oleh sejumlah besar informasi online, perdagangan, hiburan, dan jejaring sosial.

Dengan begitu banyaknya metode jaringan yang berbeda, maka diperlukan penggabungan atau penyatuan mereka semua. Robert E. Kahn dari DARPA dan ARPANET merekrut Vinton Cerf dari Stanford University untuk bekerjasama mengatasi masalah ini. Pada tahun 1973, mereka mengeluarkan suatu reformulasi mendasar, dimana perbedaan antara protokol jaringan disembunyikan dengan menggunakan protokol internetwork umum, dan bukan jaringan yang bertanggung jawab untuk keandalan, seperti dalam ARPANET, tetapi host yang bertanggung jawab.

\section{Layanan Internet,}

World Wide Web (WWW). Layanan internet yang berupa layanan www sangat populer di tengah-tengah masyarakat, layanan ini memungkinan kita semua bisa menjelajahi halaman website yang ada di internet. Para pencari informasi di internet memanfaatkan layanan www guna mencari informasi berlimpah dari internet. Sekedar mengingatkan saja meskipun layanan www ini bermanfaat sekali tetapi juga banyak sisi negatif yang juga ditawarkan seperti perjudian, pornografi, dan trafficking. E-mail (Electronic Mail): sebuah layanan untuk pengiriman surat elektronik. Untuk mengirim email kita harus mempunyai email (mailbox). Untuk membuat mailbox melalui website tertentu yang menyediakan layanan tersebut. Yahoo.com, gmail, google chroom dan sebagainya.
Mailing List sering disebut dengan milis, yaitu layanan internet sebagai pengembangan dari email yang difungsikan untuk berdiskusi. Melalui milis kita dapat menyampaikan pengumuman seperti lomba pidato, olimpiade math, science, artikel menarik, dll. Setiap email yang dikirim akan disampaikan kepada seluruh anggota shg mendapatkan informasi. Untuk mendapatkan layanan milis kita dapat memanfaatkan fasilitas yang disediakan oleh www.yahoogroups.com. Inter Relay Chat (Chatting) Adalah fasilitas yang digunakan untuk melakukan perbincangan atau bercakap-cakap melalui internet menggunakan teks atau sering disebut dengan chatting. Newsgroup adalah aplikasi internet yang berfungsi untuk berkomunikasi antara satu dengan yg lain guna membahas suatu topik dalam sebuah forum. Grup-grup akan menjadi sarana pertemuan jarak jauh secara elektronik.

File Transfer Protocol (Ftp) adalah fasilitas untuk mengirim suatu file yang disertakan melalui e-mail. File yang dikirim dapat berupa file naskah (word), gambar, animasi, musik dan sebagainya. Teleconference adalah fasilitas internet yang juga digunakan untuk berbincang-bincang dengan cara yang kompleks yaitu mulai dari suara hingga gambar, sehingga seolah-olah kita dapat langsung berhadapan dengan lawan bicara.

Fasilitas ini merupakan pengembangan dari chatting. Komputer yang digunakan untuk teleconference harus dilengkapi dengan web camera, sound card, VoIP. Fasilitas ini sangat cocok untuk melakukan rapat atau pertemuan jarak jauh karena bisa saling memandang dan mendengar secara langsung. Internet Fax, Internet juga dapat digunakan untuk mengirim faximili yang secara umum dilakukan melalui mesin faksimili. Biaya yang dibebankan adalah biaya lokal atau sama dengan internet. Fasilitas ini sangat mempermudah para sekretaris perusahaan untuk mengirim faksimili dalam jumlah yang banyak. ; Voip, Voice Over Internet Protocol (VOIP) merupakan layanan internet yang memungkinkan pembicaran via telephone dengan biaya gratis. Jika menggunakan layanan internet yang satu ini hanya memerlukan koneksi internet tanpa harus membayar pulsa telepon.

Banyak sekali VOIP server gratis yang bisa digunakan untuk layanan internet ini salah satunya yang paling terkenal di Indonesia adalah VOIP rakyat. VOIP yaitu fasilitas untuk berkomunikasi dengan suara melalui internet menggunakan pesawat telepon. Pulsa yang dibayar sama dengan pulsa internet walapun dilakukan secara SLJJ atau SLI. Software yang digunakan untuk telephony adalah Net2phone, buddytalk, media ring talk dan sebagainya. 


\section{Definisi Streaming}

Berdasarkan kajiannya terhadap hasil penelitian sebelumnya Arsam, Arfiandy (2012) Streaming adalah suatu teknologi untuk memainkan file audio atau video secara langsung maupun dengan prerecord dari sebuah mesin server (web server). File audio atau video yang terletak pada sebuah server dapat secara langsung dijalankan pada komputer client sesaat setelah ada permintaan dari pengguna sehingga proses download file tersebut yang menghabiskan waktu cukup lama dapat dihindari.

Saat file tersebut di-stream maka akan terbentuk sebuah buffer di komputer client dan data audio atau video tersebut akan mulai di-download ke dalam buffer yang telah terbentuk pada mesin client. Setelah buffer terisi dalam waktu hitungan detik, maka secara otomatis file video ataupun audio akan di jalankan oleh sistem. Sistem akan membaca informasi dari buffer sambil tetap melakukan proses download file sehingga proses streaming tetap berlangsung ke mesin client.

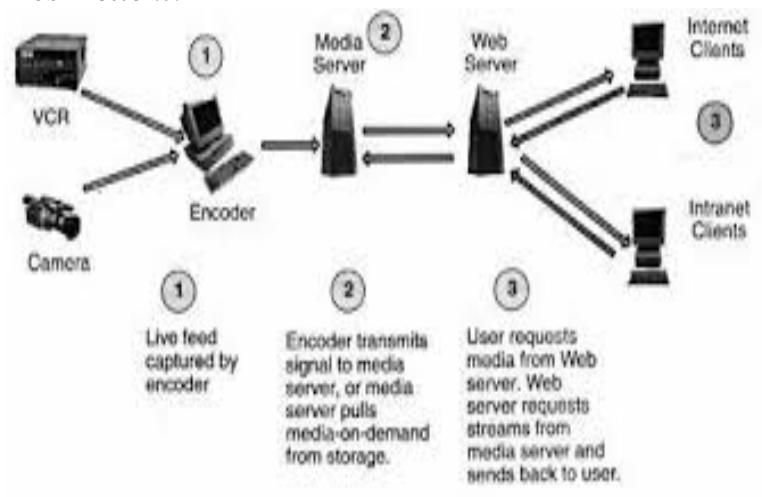

Sumber : Safars (2010)

Gambar Konsep Video Streaming

Metode streaming digunakan untuk berusaha mengatasi masalah yang terdapat dalam metode download. Ide dasar dari video streaming adalah membagi paket video menjadi beberapa bagian, mentransmisikan paket data tersebut, kemudian penerima (receiver) dapat mendecode dan memainkan potongan paket video tersebut tanpa harus menunggu keseluruhan file selesai terkirim ke mesin penerima.

\section{Format Streaming.}

Setidaknya ada tiga jenis format streaming yang banyak digunakan di situs-situs Internet. Format tersebut adalah keluaran MPEG, Windows Media dan QuickTime outdated . Masing-masing format tersebut memiliki kekurangan dan kelebihan sendirisendiri. Format Windows Media cukup handal di proses streaming, tetapi tidak terlalu handal untuk proses editing dan playback lokal. Sedangkan format
QuickTime dan MPEG rata- rata cukup handal untuk proses streaming, editing dan playback lokal.

\section{Arsitektur Streaming}

Sistem streaming tersusun dari kombinasi server , player, transmisi dan metode encoding yang digunakan. Berikut ini bagian hubungan setiap komponen penyususun sistem streaming. Untuk framework aplikasi video streaming protokol pada layer network akan menggunakan model IP (Internet Protokol), sedangkan untuk layer transpot protokol yang dipakai merupakan gabungan antara TCP (Transport Control Protokol) dan UDP (User Datagram Protocol).

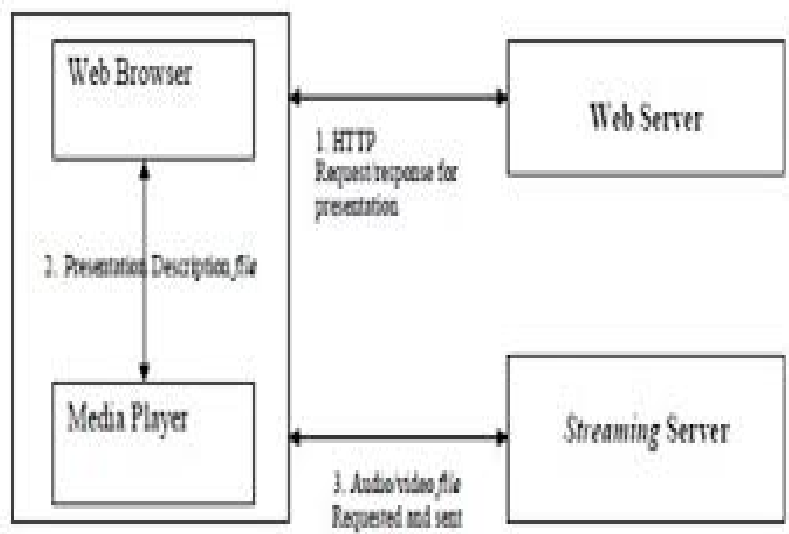

Gambar Arsitektur Streaming Sumber : Safars (2010)

\section{Metode Streaming.}

Dalam proses streaming terdapat beberapa metode, antara lain : (1) Broadcast, Broadcast adalah bentuk komunikasi one to many (yang pada dasarnya one to all) yang paling dikenal, salah satu contohnya adalah siaran TV. Dengan menggunakan broadcast maka informasi yang akan dikirim berasal dari satu sumber atau titik kepada semua penerima yang tergabung dalam jaringan. Pada broadcast semua penerima mau tidak mau akan menerima informasi ini. (2) Multicast, Multicast juga merupakan bentuk komunikasi one to many, tetapi tidak seperti broadcast. Pada multicast informasi yang dikirimkan berasal dari satu sumber atau titik kepada semua penerima yang menginginkan informasi tersebut. Server akan membuat stream satu kali kemudian stream ini diduplikasi dan dikirimkan ke setiap client. Setiap client akan menerima stream yang sama dengan client lainnya. Salah satu contoh penggunaan multicast adalah live video (3) Unicast, Unicast merupakan bentuk komunikasi one to one atau point to point. Pada unicast informasi yang dikirmkan berasal dari satu sumber atau titik ke satu titik lainnya. (4) Server, akan mengirimkan file 
streaming ke komputer client berkali-kali bergantung pada banyaknya jumlah permintaan. Setiap client akan menerima file streaming yang terpisah dari client lainnya. Contoh pengggunaan unicast adalah video on demand.

\section{Komponen-Komponen dalam Media Streaming}

Streaming media merupakan suatu sistem yang terdiri dari komponen-komponen yang diperlukan untuk melakukan streaming media adalah sebagi berikut : (1) Media Source. Media Source yaitu sumber yang akan menampilkan suatu content presentasi. Media source dapat berupa sumber yang sifatnya live, seperti kamera video dan microphone. (2) Encoder. Encoder adalah program yang digunakan untuk mengubah media source ke format yang sesuai untuk streaming. Biasanya memiliki kompresi yang cukup tinggi untuk mengatasi keterbatasan bandwidth jaringan. (3) Media Server. Media server digunakan untuk mendistribusikan video streaming ke client. Juga bertanggung jawab untuk mencatat semua aktivitas streaming, yang nantinya digunakan untuk statistik. (4) Player. Player dibutuhkan untuk menampilkan atau mempresentasikan content multimedia (data stream) yang diterima dari multi server. File-file khusus yang disebut metafile digunakan untuk mengaktifkan player dari halaman web. Metafile berisi keterangan dari content multimedia. Browser web mendownload dan meneruskan ke player yang tepat untuk mempresentasikannya. Selain itu, juga berfungsi untuk melakukan dekompresi.

\section{Masalah Streaming Media}

Dalam melakukan streaming multimedia, untuk menghasilkan presentasi yang baik seringkali timbul kendala. Kendala-kendala yang dapat terajadi dalam melakukan streaming multimedia adalah sebagai berikut:

\section{Bandwidth}

Sangat berpengaruh terhadap kualitas presentasi suatau data stream. Disamping kondisi jaringan junga mempengaruhi bandwidth, hal yang perlu diperhatikan adalah ukuran data stream harus sesuai dengan kapasitas bandwidth jaringan. Untuk mengatasinya digunakan kompresi data dan penggunaan buffer.

\section{Delay}

Merupakan waktu tunda antara data terkirim dengan data diterima. Disebabkan oleh sistem antara lain adalah proses encoder, masuknya sinyal data ke server sebelum diteruskan ke client, dan juga karena masuknya ke buffer streaming selama beberapa detik.

\section{Sinkronisasi}

Agar media yang berbeda sampai dan dipresentasikan pada user seperti aslinya, maka media tersebut harus tersinkronisasikan sesuai dengan timeline presentasi tersebut dan delay seminimal mungkin.

\begin{tabular}{|c|c|c|c|c|c|c|}
\hline & Н.261 & H.263 & H.264 & $\begin{array}{c}\text { MPE } \\
\text { G-1 }\end{array}$ & $\begin{array}{c}\text { MPEG- } \\
2\end{array}$ & $\begin{array}{c}\text { MPEG } \\
-4\end{array}$ \\
\hline $\begin{array}{c}\text { Form } \\
\text { at }\end{array}$ & $\begin{array}{c}\text { CIF/QCI } \\
\text { F } 29.97 \\
\text { FPS } \\
\text { (MAX) }\end{array}$ & $\begin{array}{c}\text { Fleksi } \\
\text { bel } \\
\text { (Pada } \\
\text { umum } \\
\text { nya } \\
\text { QCIF) }\end{array}$ & $\begin{array}{c}\text { Fleksi } \\
\text { bel }\end{array}$ & $\begin{array}{l}\text { SIF } \\
30 \\
\text { fps }\end{array}$ & $\begin{array}{c}\text { Fleksib } \\
\text { el }\end{array}$ & $\begin{array}{c}\text { Fleksi } \\
\text { bel }\end{array}$ \\
\hline $\begin{array}{c}\text { Bit } \\
\text { Rate } \\
\text { Kom } \\
\text { presi }\end{array}$ & $\begin{array}{c}\text { Px64kbp } \\
\text { s p=1,2, } \\
\ldots, 30\end{array}$ & $\begin{array}{c}<28.8 \mathrm{k} \\
\text { bps }\end{array}$ & $\begin{array}{c}\text { Fleksi } \\
\text { bel }\end{array}$ & $\begin{array}{c}1.5 \\
\text { Mbp } \\
\text { s }\end{array}$ & $\begin{array}{c}>2 \\
\text { Mbps }\end{array}$ & $\begin{array}{c}\text { Fleksi } \\
\text { bel }\end{array}$ \\
\hline $\begin{array}{c}\text { Aplik } \\
\text { asi }\end{array}$ & $\begin{array}{l}\text { Videoph } \\
\text { one/ } \\
\text { Videoco } \\
\text { nferenci } \\
\text { ng }\end{array}$ & $\begin{array}{l}\text { Video } \\
\text { phone }\end{array}$ & $\begin{array}{c}\text { Multi } \\
\text { media } \\
\text { Web } \\
\text { Video }\end{array}$ & $\begin{array}{c}\text { Vide } \\
\text { o } \\
\text { Casst } \\
\text { te } \\
\text { Reco } \\
\text { rder } \\
\end{array}$ & $\begin{array}{l}\text { Berbag } \\
\text { ai } \\
\text { macam } \\
\text { aplikasi } \\
\text { video }\end{array}$ & $\begin{array}{c}\text { Multi } \\
\text { media } \\
\text { Web } \\
\text { Video }\end{array}$ \\
\hline $\begin{array}{c}\text { Trans } \\
\text { port }\end{array}$ & N-ISDN & $\begin{array}{c}\text { Kabel } \\
\text { telepn } \\
\text { dan } \\
\text { Wirele } \\
\text { ss }\end{array}$ & $\begin{array}{c}\text { Berba } \\
\text { gai } \\
\text { maca } \\
\text { m } \\
\text { media }\end{array}$ & $\begin{array}{c}\text { ADS } \\
\text { L }\end{array}$ & $\begin{array}{c}\text { DVD } \\
\text { dan } \\
\text { Digital } \\
\text { TV } \\
\text { Broadc } \\
\text { ast } \\
\end{array}$ & $\begin{array}{c}\text { Berba } \\
\text { gai } \\
\text { maca } \\
\text { m } \\
\text { media }\end{array}$ \\
\hline
\end{tabular}

Sumber : ITSN (2007)

Tabel Perbandingan Standar Kompresi

Adanya kerugian sinkronisasi dan delay dapat disebabkan oleh kondisi jaringan yang buruk, sehingga mengakibatkan timeline presentasi menjdi kacau. (4) Interoperability, Idealnya adalah presentasi yang kita buat harus dapat dimainkan oelh semua jenis client, CPU yang berbeda, sistem operasi yang berbeda, media player lainnya dan smartphone yang digunakan. Khusus untuk masalah yang berhubungan dengan kondisi bandwidth jaringan dapat diatasi dengan menerapkan teknologi LTE atau 4G. Teknologi ini dapat menyediakan lintasan data dengan kecepatan transfer yang tinggi. Dengan menerapkan teknologi 4G diharapkan mampu menyelenggarakan live video streaming dengan kualitas yang baik sekaliguas menjadi alternative untuk melakukan berbagai macam aplikasi seperti TV on demand, live TV, maupun belajar jarah jauh (e-learning).

\section{Standar Kompresi Video}

Standardisasi terhadap kompresi informasi audiovisual diperlukan untuk memfasilitasi pertukaran data berupa video digital secara global. Sebuah standardisasi pengkodean dikatakan efisien bila mendukung algoritma kompresi yang baik dan 
mengimplementasikan disain enkoder dan dekoder yang efisien. Untuk komunikasi multimedia, terdapat dua organisasi standard yang utamayaitu ITU-T dan International Organization for Standardization (ISO). Selama beberapa dekade belakangan ini, sejumlah standard dari ITU-T dan ISO, seperti MPEG-1, MPEG-2, MPEG-4, H.261, H.263 dan H.264 telah dikembangkan untuk banyak domain aplikasi.

Standard-standard tersebut mendefinisikan bitstream dari data audio-visual dan menentukan sekumpulan aturan yang harus dipatuhi dalam pengembangan hardware maupun software untuk solusi kompresi. Standardisasi kompresi video tidak dengan tegas menentukan proses pengkodean, tetapi mengambil kelebihan dari riset-riset dalam bidang teknik kompresi yang banyak dilakukan dan merekomendasikan sejumlah agoritma untuk memperoleh teknik kompresi dan dekompresi yang efisien.

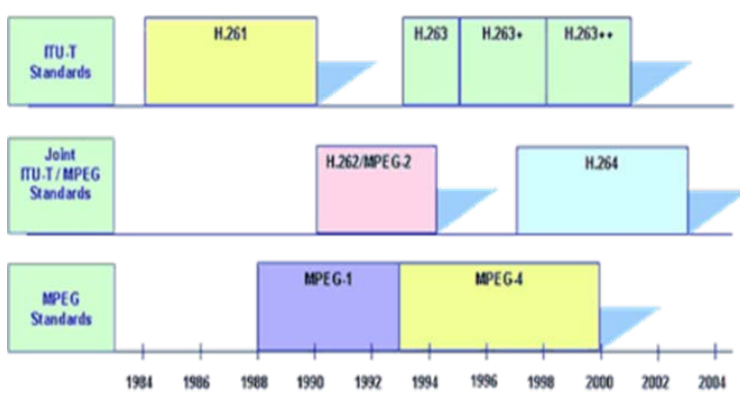

Sumber : Satwika (2011)

Gambar Standar Kompresi

\section{Android}

Android adalah sebuah sistem operasi untuk perangkat mobile bebasis linux yang mencakup sistem operasi, middleware dan aplikasi. Android menyediakan platform yang terbuka bagi para pengembang untuk menciptakan aplikasi mereka. Awalnya, google Inc membeli Android Inc. yang merupakan pendatang baru yang membuat piranti lunak untuk ponsel/smartphone. Kemudian untuk mengembangkan android dibentuklah Open Handset Alliance, konsorsium dari 34 perusahaan piranti lunak, piranti keras dan telekomunikasi, termasuk Google, HTC, Intel, Motorola, Qualcomm, TMobile dan Nvidia. Pada saat perilisan perdana android 5 November 2007. android bersama Open Handset Alliance menyatakan mendukung pengembangkan open source pada perangkat mobile. Di lain pihak, google merilis kode-kode android dibawah lisensi Apache, sebuah aplikasi lisensi perangkat lunak dan open platform perangkat seluler.

\begin{tabular}{|c|c|c|}
\hline Android & Code Name & $\begin{array}{l}\text { Tanggal } \\
\text { Peluncuran }\end{array}$ \\
\hline $\begin{array}{l}\text { Android versi } \\
1.1\end{array}$ & - & 09 Maret 2009 \\
\hline $\begin{array}{l}\text { Android versi } \\
1.5\end{array}$ & Cupcake & 30 April 2009 \\
\hline $\begin{array}{l}\text { Android versi } \\
1.6\end{array}$ & Donut & $\begin{array}{l}15 \text { September } \\
2009\end{array}$ \\
\hline $\begin{array}{l}\text { Android versi } \\
2.0 / 2.1\end{array}$ & Eclair & 26 Oktober 2009 \\
\hline $\begin{array}{l}\text { Android versi } \\
2.2\end{array}$ & $\begin{array}{l}\text { Frozen } \\
\text { Yoghurt } \\
\text { (Froyo) }\end{array}$ & 20 Mei 2010 \\
\hline $\begin{array}{l}\text { Android versi } \\
2.3\end{array}$ & Gingerbread & $\begin{array}{ll}06 & \text { Desember } \\
2010 & \end{array}$ \\
\hline $\begin{array}{l}\text { Android versi } \\
3.0 / 3.1\end{array}$ & Honeycomb & 22 Februari 2011 \\
\hline $\begin{array}{l}\text { Android versi } \\
4.0\end{array}$ & $\begin{array}{l}\text { Ice Cream } \\
\text { Sandwich (ICS) }\end{array}$ & 19 Oktober 2011 \\
\hline $\begin{array}{l}\text { Android versi } \\
4.1 / 4.2\end{array}$ & Jellybean & 09 Juli 2012 \\
\hline $\begin{array}{l}\text { Android versi } \\
4.4\end{array}$ & Kitkat & 31 Oktober 2013 \\
\hline
\end{tabular}

Sumber : Wegito (2007)

Tabel Versi Android

\section{KESIMPULAN}

Berdasarkan pengamatan dan penelitian serta datadata yang diperoleh dari narasumber mengenai teknologi streaming yang dimanfaatkan di LPP TVRI Jawa Barat, maka penulis dapat mengambil kesimpulan sebagai berikut :

Teknologi video streaming yang dimanfaatkan di LPP TVRI Jawa Barat, dimaksudkan untuk 
memenuhi kebutuhan khalayak akan informasi dan hiburan. Khalayak berhak memilih program acara yang akan disaksikan sesuai dengan keinginannya. Dengan pemanfaatan teknologi video streaming khalayak yang berada di luar rumah, seperti di kantor, café atau diluar wilayah Jawa Barat dapat dengan mudah dan praktis menyaksikan program acara LPP TVRI nasional atau LPP TVRI daerah di Indonesia melalui smartphone, android, Ipad atau berbagai gadget dengan masuk ke youtube atau aplikasi TVRI live streaming yang dapat didownload di playstore.

Perkembangan teknologi video streaming LPP TVRI Jawa barat sama dengan stasiun televisi lainnya dalam hal visual, tetapi yang membedakan streaming TVRI dengan stasiun TV lainnya, dimana khalayak dapat memilih program acara yang mereka inginkan hanya dengan pilihan channel yang terdapat di aplikasi TVRI live streaming, khalayak dengan mudah dapat menyaksikan program acara baik itu LPP TVRI Jawa Barat maupun LPP TVRI daerah lainnya.

Teknologi video streaming yang dimanfaatkan di LPP TVRI Jawa Barat sangat berdampak baik terhadap stasiun TV maupun terhadap publik. Dengan adanya video streaming LPP TVRI Jawa Barat tidak tertinggal dalam perkembangan teknologi. LPP TVRI Jawa Barat dapat bersaing dengan stasiun TV daerah maupun nasional dalam pemanfaatan teknologi video streaming, terutama LPP TVRI adalah stasiun TV pertama yang memanfaatkan teknologi video streaming dan LPP TVRI Jawa Barat berada di dalamnya, sedangkan bagi masyarakat teknologi video streaming sangat membantu dalam kebutuhan masyarakat akan informasi dan hiburan, masyarakat dapat dengan mudah dan praktis menyaksikan program acara LPP TVRI Jawa barat melalui gadget dimanapun dan kapanpun.

Kelebihan Teknologi video streaming yang dimanfaatkan di LPP TVRI Jawa Barat : Jaringan memilih terpisah terutama dalam video streaming supaya tidak ada kendala jaringan, Program acara yang terlewat dapat disaksikan kembali dengan memilih catchup TV yang terdapat di aplikasi TVRI live streaming. Dapat menyaksikan program acara secara gratis dan mudah, serta dapat memilih program acara yang diinginkan baik di channel LPP TVRI Jawa Barat atau LPP TVRI daerah lainnya yang terdapat di Indonesia.

Kekurangannya live streaming LPP TVRI Jawa Barat:

Program acara live streaming LPP TVRI Jawa Barat dapat disaksikan mulai pukul 15.00 pada program acara kalawarta sampai pukul 21.00 pada program acara musikan. Untuk di youtube saat memilih program acara LPP TVRI Jawa Barat yang muncul adalah program live TVRI Nasional, karena live streaming LPP TVRI Jawa Barat dimulai pukul 15.00 Judul program LPP TVRI Jawa Barat yang tersedia di youtube saat dipilih masih kosong, sehingga user harus mengetik program yang diinginkan di mesin pencari. Kendala yang di hadapi LPP TVRI Jawa Barat dalam video streaming adalah jaringan internet yang digunakan user.

\section{REFERENSI}

Adila, A Aprizal, dkk. (2009). Video Streaming dengan Video LAN Project. Elektron, Vol. 1 No. 2, hal. 87-79.

Ardianto, Elvinaro, Lukita Komala dan Siti Karlinah. (2014). Komunikasi Massa. Bandung : Penerbit Simbiosa Rekatama Media.

Arkam, Arfiandy. (2012). Pembangunan Aplikasi Video Streaming berbasis Android di STV Bandung. Jurnal ilmiah komputer dan informatika.

http://staf.unud.ac.id/linawati/wpcontent/uploads/2011/07/proses-videostreaming-dengan-protocol-rtsp.pdf Diakses 3 September 2012.

Institut Teknologi Sepuluh November. (2007). Jaringan HSDPA. Naskah Publikasi. Teknologi Industri, Jurusan Teknik Elektro Fakultas Surabaya.

Kurniawan. Eko. (2104). Analisis Kualitas Real Time Video Streaming terhadap Bandwitch Jaringan yang tersedia. Jurnal USU Vol. 9 No. 2 November 2014 https://jurnal.usu.ac.id/singuda_ensikom/art icle/download/7561/4019.Universitas Sumatera Utara. 2014.

Kurniawan, Wiharsono. (2007). Jaringan Komputer. Yogyakarta : Penerbit ANDI

Safars. (2010). Komunikasi Data dengan TCP dan UDP. $\quad$ http://ft.uikabogor.ac.id/safars/2010/12/komunikasidata-tcp-udp/ Diakses 5 September 2012.

Saputra, Alief Chandra Agil. (2010). Cara Cepat Bikin Live TV di Blog dan Website. Yogyakarta : Penerbit ANDI.

Satwika, I Kadek Susila. (2011). Proses Video Streaming dengan Protokol Real Time Streaming Protocol. Teknik Elektro : Universitas Udayana.

Silalahi. FE. (2013). Studi Dan Analisis Video Streaming Via Wireless LAN. Jurnal for PCR,

https://jurnal.pcr.ac.id/index.php/jakt/ar ticle/view/320. Jurnal Aksara Komputer Terapan, Politeknik Caltex Riau. 
Suhendra, Made. (2009). Analisa Perfomansi Live Streaming dengan menggunakan. Surakarta : Universitas Muhammadiyah.

Wegito. (2007). Jaringan Komputer Teori dan Implementasi Berbasis Linux. Penerbit Gava Media : Yogyakarta.

\section{PROFIL PENULIS}

Lia Kurniawati, S. Ikom., M. MPd., merupakan dosen ilmu komunikasi pada program studi Broadcasting Journalism (Penyiaran Radio dan Televisi). Saat ini menjabat sebagai Direktur Politeknik Kridatama dimana Politeknik Kridatama merupakan sebuah lembaga pendidikan tinggi penyelenggara program studi Penyiaran Radio Televisi, Administrasi Bisnis dan Manajemen Informatika. Penulis lahir di Bandung pada tahun 1978. Beberapa prestasi beliau salah satunya tergabung dalam sebuah asosiasi Penulis Perempuan Tingkat ASEAN (AWWA) kepanjangan dari
Association Woman Writer of ASEAN. Copy Writer untuk iklan media online, kontributor majalah Ummi, juga peraih hibah penelitian kompetitif nasional dari Direktorat Jenderal Penguatan Riset dan Teknologi Pendidikan Tinggi (Ditjendikti) tahun 2018 lalu. Salah satu buku ajar yang telah diterbitkan berjudul "Psikologi Komunikasi" dipakai untuk mahasiswa Program Studi Ilmu Komunikasi baik untuk Diploma III, Strata-1 bahkan untuk umum, menulis buku-buku dengan genre populer, serta beberapa modul bahan ajar yang dipakai untuk lingkungan sendiri (Politeknik Kridatama). Mata kuliah yang diampu yaitu : SDM Anggaran Siaran, Etika Profesi Jurnalistik, Teknik Penulisan Laporan Akhir, Komunikasi Massa, Pengantar Ilmu Komunikasi, Public Relation and Communication, Advertising, Komunikasi Bisnis, Character Building, Sistem Informasi Manajemen, Psikologi Komunikasi, Cyber Media, Teknik Tulis Berita. 